\title{
From Soft to Structured Regionalism: Building Regional Institutions in the Asia-Pacific
}

\author{
Suisheng Zhao
}

Published online: 5 September 2013

(C) CEEUN 2013

\begin{abstract}
Most Asian countries were reluctant to commit to regional institutions and felt more comfortable with cooperation in decentralized and non-institutionalized settings, or a soft approach toward regionalism. In explaining the persistence of soft regionalism, realist scholars often cite the sheer size and diversity in the form of historical legacies, economic and ideological differences, and ambiguous geographical boundaries as particularly daunting obstacle to any formal efforts to institutionalize regional cooperation in Asia-Pacific. In contrast, liberal scholars have used integration theory to argue that, as a result of political spillover of economic interdependence, Asian regionalism is inevitable and will resemble Europe's model of regional integration. This paper argues that each of the above two explanations captures only part of the truth. On the one hand, although the size and diversity of regions do not prevent regionalism from occurring, they are important variables to influence negotiations of regional institution-building efforts. On the other hand, while economic interdependence indeed facilitates regional cooperation, it does not dictate the organizational choice of regional cooperation. Going beyond economic variables, this paper examines the changing political environment that created new incentives for building regional institution in the Asia-Pacific after the end of the Cold War and how sheer size and diversity of the region has produced a unique Asian style of regionalism, exemplified in the ASEAN and APEC Way of Institution-building.
\end{abstract}

Keywords Regionalism · Asia-Pacific · Economic interdependence · ASEAN $\cdot$ APEC $\cdot$ Regional institution building

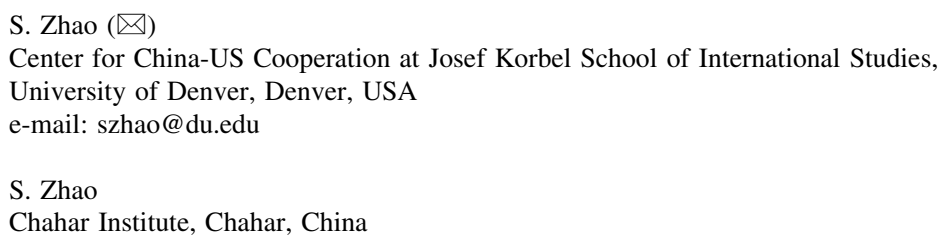




\section{Introduction}

Most Asian countries traditionally favored bilateralism rather than multilateralism in dealing with regional issues. As a result, they were reluctant to commit to regional institutions and felt more comfortable with cooperation in decentralized and non-institutionalized settings. In a comparison, Robert Gilpin pointed to a "politically motivated and institutionalized movement" toward regional integration in Western Europe and a "primarily economic and less institutionalized nature" of regional cooperation in East Asia (Gilpin 1993, p. 33). When regional cooperation did occur, it has focused mostly on non-traditional security issue areas and rarely adventured into resolution of contentious territorial disputes and other traditional security conflicts because "in a region where historical animosities remain high, non-traditional issues can avoid sensitive areas and find common ground for cooperation that traditional security approaches would be unable to envisage" (Cui 2013). Robert Scalapino used the concept of "soft regionalism" to characterize the regional cooperation in the Asia-Pacific that "lacks a formal structure" (Scalapino 1987, p. 7). In explaining the persistence of soft regionalism, realist scholars often cite the sheer size and diversity "in the form of historical legacies, economic and ideological differences, and ambiguous geographical boundaries" as "particularly daunting obstacles" to any formal efforts to institutionalize regional cooperation in Asia-Pacific (Fields 1992, p. 87). From this perspective, it is even argued that the region "was built on sandy soil, making it unsuitable for cultivating a sense of community and regional institutions".

Indeed, Asia consists of a very diverse group of peoples and cultures, all at varying stages of economic development. A Japanese scholar lists many factors constraining structured regional undertakings. These included "the diversity and/or conflicts of national interests; the fear among smaller member countries of largecountry domination and exploitation; the diversity of historical and economic linkages with outside powers; and the lack of cultural, linguistic, and historical ties among themselves" (Hirono 1988, p. 99). This view argues that the nature of structured regionalism would make it difficult to get success in a large and diversified part of the world under anarchy unless a hegemonic power emerges to enforce its vision. ${ }^{1}$ Anarchy in a highly diverse area discourages structured regionalism "because it requires states to worry about the relative gains of cooperation and the possibility that adversaries will cheat on agreements" (Glaster 1994/95, p. 50). International anarchy fosters competition and conflict among states and inhibits their willingness to cooperate even when they share common interests. ${ }^{2}$ In this case, the only hope for building strong regional institutions is to have a hegemonic power that is interested and willing to enforce the initiatives.

\footnotetext{
${ }^{1}$ According to hegemonic stability theory, there must be a hegemon, namely, a single dominant power, to ensure international stability and, hence, to endure most of the cost of international institution-building under anarchy. See, for example, (Kindleberger 1975; Krasner 1976; Keohane 1984).

2 As Kenneth Waltz points out, "the fiercest civil wars and the bloodiest international ones are fought within arenas populated by highly similar people whose affairs are closely knit" (Waltz 1979, p. 138). John Lewis Gaddies also argues that economic interdependence can do little to prevent states from going to war (Gaddies 1989, p. 12).
} 
While the size and diversity of Asia has not been changed in any fundamental way and nor has a single hegemonic power dominating the Asia-Pacific since the end of the Cold War, interest in multilateral or collective actions in coping with the region's economic and political dynamism has surged, represented by the institution-building efforts of the APEC, the ASEAN Regional Forum, ASEAN-plus-3 framework, and burgeoning Free Trade Agreements (FTAs). While realist theory cannot easily explain the emergence of newly founded interests in regional institutions, liberal scholars have used integration theory to explain it as a result of political spillover of economic interdependence. It argues that the formation of "interdependent patterns" of relations in the region created "a greater convergence of interests in mutual management" (Crone 1993, pp. 503-505). According to this theory, growing interdependence becomes the most important factor contributing to "a sense of community ripe for the advance toward regional integration" (Chow 1993, p. 195). Common economic interests create the demand for the establishment of international institutions and rules. $^{3}$ A linear and essentially irreversible movement toward economic interdependence is a driving force toward ever-higher levels of economic integration (Bergsten 1988, p. 60). Asian regionalism, by this logic, is inevitable and will resemble Europe's model of regional integration. As Asia proceeds down the path of regional integration, it has to look to the European Union (EU) as a successful model and European experience may provide useful signposts for Asian regional initiatives.

However, "it is dangerous to apply the European 'past' to the East Asian "future," because there are distinctive differences in regional characteristics underpinning the two regions (Hidetaka 2006, p. 1). These differences have produced a different scope and organizational arrangement of regionalism in East Asia and Europe. The Asian Pacific institution-building process has been uniquely Asian, characterized by consensus building, voluntarism and open regionalism rather than building supranational governing structure such as European Commission and the European Court of Justice to enforce binding decisions.

Based on this observation, this paper argues that each of the above two explanations captures only part of the truth. On the one hand, although the size and diversity of regions do not prevent regionalism from occurring, they are important variables to influence negotiations of regional institution-building efforts. On the other hand, while economic interdependence indeed facilitates regional cooperation, it does not dictate the organizational choice of regional cooperation. Going beyond economic variables, this paper examines the changing political environment that created new incentives for building regional institution in the Asia-Pacific after the end of the Cold War and how sheer size and diversity of the region has produced a unique Asian style of regionalism, exemplified in the ASEAN and APEC Way of Institution-building.

\footnotetext{
3 Robert Keohane cites this position of David Mitrany, as exemplifying what he terms an “institutionalist" view. See (Mitrany 1975) For Keohane's citation, see After Hegemony, pp. 7-8.
} 


\section{Organizational Choice of Regionalism: Soft Versus Structured}

Regionalism in Asian-Pacific, defined here as including all continental and maritime Asian countries east of Bangladesh, has taken two major organizational forms: one soft and the other structured or institutionalized. Soft regionalism may be defined as cooperation among geographically close nations or economies without formal institutional arrangements. In contrast, structured regionalism ties countries together by formal intergovernmental agreement with the underlying idea of a lasting interrelationship and thus often involves certain types of supranational institutions. There is often a gliding transition from soft to structured regionalism. Nevertheless, soft regionalism does not necessarily lead to structured regional integration because structured regionalism often touches, sometimes more palpable, sometimes in a minor degree, the sensitive point of national sovereignty. A fully developed and structured regional scheme always implies partial transfer of national sovereignties to supranational institutions, although structured regionalism does not necessarily supersede nation-state actors; nor does the establishment of structured regional organizations necessarily mean a decline of nation-states as James Rosenau predicted. $^{4}$

\section{Barriers to Structured Regionalism}

There are a number of major obstacles to East Asian regional cooperation (Moore 2013). Many Asia-Pacific countries have been reluctant to accept structured regionalism due to "the traditional Asian distaste for treaty-defined institutions" (Clark Clarke 1995, p. 85), reflecting the region's unique culture, history, evolving socio-economic and political conditions, in addition to the problem identified by neo-realists as "the effects of structure on cooperation" (Axelrod and Keohane 1993, p. 87). To a great extent, past humiliating experiences of many Asian-Pacific countries in the hands of imperialist powers still shadow their perception of the future. While many Asia-Pacific countries were victimized by colonial powers in the 19th century, they have ironically embraced the Western-introduced sovereignty concept with a vengeance (Kim 1991, p. 5; Seymour 1994, p. 203). Along with other parts of the World, the Asia-Pacific as a whole has entered the post-Cold War era, but some Asia-Pacific countries are still in "the post-colonial era," a fact that "heightens many Asian nations' concerns about ceding sovereignty in the name of regional integration" (The Carnegie Endowment Study Group 1994, p. 14). As Hirono indicates, no nation in Asia-Pacific, however willing to compromise in the interest of attaining the common objectives of regional groupings, "is ready to surrender sovereign rights over its domestic affairs and foreign relations" (Hirono 1988, p. 101). Small or weak nations are suspicious of what they see as attempts by the "great powers" to reassert influence in new ways. But so too are China and

\footnotetext{
${ }^{4}$ Rosenau wrote that "the nation is declining in its importance as a political unit to which allegiances are attached." For the similar views, also see (Rosenau 1968, p. 39; Herz 1968, pp. 12-34; Falk 1975; Rosecrance 1986).
} 
Japan reluctant to abandon elements of sovereignty to regional institutions without strong evidence that there is more to be gained from doing so.

In addition, the following four unique conditions also make it difficult for Asian-Pacific countries to easily accept institutionalized regionalism. First, in comparison with European states, which share valuable cultural backgrounds, including common linguistic roots, Christianity and the historical legacy of the Roman Empire, Asian nations do not share cultural backgrounds to such a significant extent. The region comprises states with Buddhist, Confucian and Islamic traditions (Hidetaka 2006, pp. 1-2). If there was a clash of civilizations, it would occur as much among the countries within the region as between Asian countries and non-Asian countries. Cultural and ethnic suspicions, therefore, have become a major barrier for building rule-based and norm driven regional institutions. Second, the national boundaries in Europe are far more contiguous than in Asia, and distances for goods to travel much shorter. When Europe began its integration process, most of its economies were more closely aligned than in today's Asia. Third is diversity. While most Asian economies thrive in an open global economy, some countries struggle in post-conflict environments; are in transition to market economies; or grapple with geographical isolation and limited markets. Fourth, Asia countries represent a wide array of political regimes and philosophies, from communist to authoritarian, from constitutional monarchies to military dictatorships, from personal dictatorship to bureaucratic governance, from democratically elected governments to single-party system. Even where governance is accomplished through democratic institutions, political styles vary and are in flux. This political diversity further complicated communications to build regional institutions.

In this case, the overall speed of integration in Europe was relatively consistent, moving from trade to finance-from customs union to common market to single currency-and finally to an economic and political union. During this process, each participating state moved forward with the others while the process of institution-building developed quickly and the European Union was formed by the voluntary transfer of certain sovereign powers to be exercised jointly. In contrast, political support for integration in Asia has been much weaker than it is in Europe. The political contrasts, ethnic suspicions and varying levels of development among Asian-Pacific countries make it harder to create shared regional sovereignty through a joint framework of supranational institutions. The efficacy of gaining political support for regional integration through institutionbuilding is difficult because it has a negative impact upon payoff structures of regional institutions by increasing the motivation of cheating and deception. Robert Axelrod's experimental study demonstrates that the greater the conflict of interest between players, the greater the likelihood that the players would in fact choose to defect (Axelrod 1967, pp. 87-89). It is from this perspective that pessimistic-realist scholars such as Manning and Stern assert that the cherished aspiration of Asia-Pacific regional institutions "may prove to be a chimera" (Manning and Stern 1994, p. 80). 
For a long period after World War II, indeed, Asia-Pacific's sheer size and extraordinary diversity, including political and ethnic suspicions, long-standing antipathies and economic disparities, were indeed major barriers to building structured regional institutions. The only regional organization, Association of Southeast Asian Nations (ASEAN), built in 1967 to work collectively in dealing with many regional issues was a classic example of soft regionalism as its goal was cooperation without integration until very recently. It consciously avoided moving in the direction of institutionalized cooperation for many years. There was not a trans-national structure to which national decision-making authority was transferred. There was no ASEAN equivalent of Brussels. It was the limited level and nature of institutionalization that "led to some dissatisfaction with the pace of functional cooperation in the region and mounting criticisms from within nonbureaucratic but still elite ASEAN circles of the inadequacy of the structures created for foster cooperation" (Weatherbee 1993, p. 31).

In the 1980s, a four tiers' model of economic development that know as the flying-geese pattern in the Asia Pacific led to a growing economic interdependence, ${ }^{5}$ which in turn, produced soft regional economic zones across national borders. Japan, as the first industrialized Asian country, played a central role to the growing network of economic ties among the nations of the region. The four tier model of industrialization and economic growth provides a continuous process of transition through successive transfers of technology, goods and capital flow from the first tier (Japan) to the second tier (four little tigers of Hong Kong, Taiwan, Singapore and South Korea), to the third tier (ASEAN countries), and to the fourth tier (China and Vietnam). Thus, a regional division of labor based on "floor type" specialization in each tier of nations makes their economies mutually supplementary and interdependence, evident in the rapid growth of intra-regional trade, which reached about $45 \%$ of total trade volume in the early 1990 s.

Asia-Pacific intra-trade grew fastest in the 1980s when the access to the US market became uncertain due to depreciation of US dollar and contentious trade policy. The sharp appreciation of Japanese yen after the so-called Plaza Accord of 1985 made East Asian manufacturers more competitive in a wide range of industries previously controlled by Japan, and also contributed to intra-regional trade (Gordon 1993, p. 63). The dispersion of manufacturing throughout the Asia-Pacific created an "interdependence between the region's more advanced economies and the next tier of industrializing countries" (Petri 1994, p. 409). A World Bank study indicated that, from the end of World War II to the 1970s, trade within Asia-Pacific was relatively unimportant because the region developed stronger connections with North America and other countries. However, the growth of the region's own markets began to outweigh the development of external markets, and internal AsiaPacific trade began to increase in the 1980s. East Asia's internal trade was only

\footnotetext{
${ }^{5} \mathrm{~K}$. Akamatsu is usually credited as the first advocate of the flying-geese theory, see (Akamatsu 1962, pp. 3-25). Also see (Bradford 1987, pp. 299-316) and (Inoguchi 1994, p. 25). For one book-length study of the four tier model, see (McCord 1993).
} 
$29.3 \%$ of its total trade in the 1960 s and rose to $40.7 \%$ in 1990 . The internal trade as a percentage of total world trade increased from 2.9 in 1969 to 7.9 in 1990 . This percentage was further increased to 12.3 in 1996 (Dent 1999, p. 17).

Growing economic interdependence led to the emergence of soft regionalism mostly in the form of growth clusters: regional economic networks formed without regard to, and often despite, national borders. These growth clusters transcended political boundaries but often did not involve entire national economies (Yue and Yuan 1993, p. 226). The most effective examples were the Pearl River economic zone, which bridges China's Guangdong Province and Hong Kong; the SingaporeJohor-Riau Growth Triangle linking Singapore, Malaysia, and Indonesia; and the economic linkage among China mainland, Taiwan, and Hong Kong, known as the Chinese Economic Area (CEA). The Mekong River development area where Burma, China, Laos, and Thailand meet is a "growth square" (Emmerson 1994, p. 437). In addition, the Sea of Japan Economic Zone includes the Russian Far East, the three northeast provinces of China, the Korean peninsula, and Japan's sixteen coastal prefectures on the Sea of Japan. The Yellow Sea Economic Zone links China, Japan and South Korea (Lu 1993, p. 4). The Tumen River Delta Area involves eastern Russia, China, South and North Koreas, Mongolia, and Japan.

The development of these soft regional mechanisms was based on geographic proximity and historical linkages as well as on comparative advantage, especially in labor costs. They were promoted mostly by an expansion of business interests. In contrast to politically driven regional integration through institutional frameworks in Europe, Asian soft regionalism occurred largely as market driven integration through the increased flow of trade and investment. They fit the region's pragmatic approach to regional cooperation because they do not require complicated legal agreements and can be implemented across diverse economic and political structures without involving the sensitive sovereignty issue. As one study of the growth triangle involving Indonesia, Malaysia, and Singapore indicated, "Problems unique to this region include the relative newness of statehood of countries involved in the project. All three countries jealously guard their statehood and are unwilling to relinquish executive functions to a supranational authority. In this regard, whereas Western European states may have entered a new political epoch following centuries of statehood, there is little evidence to suggest that Southeast Asian states are interested or prepared to part with their political sovereignty and territorial integrity" (Ganesan 1993, p. 6).

\section{Transformation from Soft to Structured Regionalism}

While some of the growth clusters remains soft, some others have transformed to structured regional cooperation through intergovernmental agreements. One example is the development of Tumen River area in Northeast Asia. The initial UNDPsponsored project in 1991 straddles the border region between North Korea, Pacific Russia, and China's Jilin province. South Korea and Japan are potential beneficiaries and sources of the enormous financing that is required. Land-locked Mongolia's interest lies with the possibility of gaining another less congested link with the Pacific (Marton et al. 1995, pp. 8-33). When the project was launched, it 
could only be soft regionalism in nature because China did not have official diplomatic relationship with South Korea, and relations between two Koreas and between Japan and Russia were still tense. The dramatic changes of later years eased political tensions to a point where all six political entities concerned could sit at the same table. Three governments (China, Russia, and North Korea) signed an agreement to establish the Tumen River Area Development Coordinating Council on May 30, 1995. Two other agreements were signed by five governments (China, Russia, Mongolia, South and North Koreas) on the same day: one to establish the Tumen River Area Development Consulting Council, and the other to set up guidelines for environmental protection in the subregional development. With these inter-governmental agreements, the soft Tumen River area cooperation was transformed into a structured one.

As a matter of fact, structured regionalism has gradually emerged in the AsiaPacific in the recent years. Economic interdependence is certainly an important factor that has greatly contributed to the recent emergence of Asia-Pacific regionalism because it has changed perceptions of the payoff structure of regional cooperation. As a report of the Carnegie Endowment study group indicates, "The relationships among most East Asian states today probably reflect less a heritage of animosity and more a common participation in the modernization process-a global phenomenon"(The Carnegie Endowment Study Group 1994, p. 16). Economic interdependence has made cooperative solutions more attractive and is breaking down Asian parochialism and encouraging Asia-Pacific leaders to think regionally.

Nevertheless, just as "interdependence is not the opposite of anarchy" (Milner 1993, p. 163), interdependence does not necessarily result in a willingness to shift even part of national sovereignty to supranational institutions. ${ }^{6}$ While interdependence signifies mutual dependence, it is a situation in which nation-states are linked but remain sovereign. There are two distinct uses for the concept of interdependence. $^{7}$ One refers to a relationship of sensitivity, in which there is simply a covariance in the behavior of two or more states. The second use refers to a relationship of vulnerability, in which one state depends on another for the provision of a commodity or other valued need and cannot move to another supplier without incurring high costs see (Baldwin 1980, pp. 471-506; Cooper 1972, p. 159). The concept of interdependence in the sense of vulnerability is "the most well accepted definition" (Milner 1993, p. 168) and is helpful in analyzing the dynamic relationships that link sovereign states together in regional cooperation.

In this sense, interdependence implies a relationship in which "the ability of one participant to gain his ends is dependent to an important degree on the choice or decisions that the other participant will make" (Schelling 1960, p. 5). In this relationship, nation-states are still sovereign, that is, able to make decisions or choices autonomously, although to realize their goals they must be concerned with

\footnotetext{
6 According to the definition by Barkin and Cronin, legitimate authority and territoriality are the key concepts in understanding national sovereignty (Barkin and Cronin 1994, pp. 107-130).

7 The concept of interdependence has come into a precise scholarly usage since the publication of Richard N. Cooper's The Economics of Interdependence: Economic Policy in the Atlantic Community (Cooper 1968) and Keohane and Joseph S. Nye's Power and Interdependence: World Politics in Transition (Nye 1977).
} 
the choices that other states make. ${ }^{8}$ This definition of interdependence does not imply either that the interests of nation-states are in harmony or that asymmetric relations are not important. Due to the differences in size, political and economic resources, larger or more powerful nations involved in an asymmetric interdependent relationship can manipulate it in order to prompt the smaller or weaker nations to do what they want. That is why sovereignty has remained the central concern of many Asia-Pacific states when growing interdependence makes cooperation a more and more attractive choice.

While economic independence cannot explain the movement toward structured regionalism, nor does realist theory that looks for a hegemonic power to enforce the initiatives of institutionalized regionalism. During the Cold War era, the US and the Soviet Union were two superpowers competing for predominance in the region. When the Soviet Union collapsed at the end of the Cold War, US power also has declined at least relatively in this region. Surely, the US is still a critical actor. But an irony is that, while in absolute terms US engagement in the Pacific is steadily increasing, it is declining in relative terms. What stands out in the region is a shared unease at perceived trends: a contraction of the central economic and military role played by the US, simultaneous with the ascendance of China and Japan as multifaceted powers. Nevertheless, neither China nor Japan is close to being a hegemonic power in the region, and neither of them can play the leadership role to peacefully energize its neighbors. ${ }^{9}$

Without a hegemonic power, this paper looks at how the changing regional political environment brought about by three dramatic shocks- the end of the Cold War, the Asian Financial Crisis of 1997-98, and the terrorist attack on September 11, 2001-have generated political support for institutionalized regionalism. These shocks fundamentally changed regional political dynamics and, therefore, became the most important catalysts for the development of structured regionalism (Aggarwal and Koo 2006, p. 30).

In the Cold War bipolar system, while the US provided security protection and offered market access to its Asia-Pacific allies through many bilateral arrangements, the Soviet Union worked hard to make its own bilateral arrangements with Asia-Pacific countries. Therefore, there were few political incentives for AsiaPacific to develop regional security and economic institutions. The end of the Cold War not only brought to the ended of the divisive superpower rivalry but also made it necessary for Asia-Pacific countries to develop their own regional institutions because of the disappearance of many bilateral security and economic arrangements associated with two superpowers. In the meantime, the end of the Cold War also brought many non-traditional security threats largely ignored during the Cold War years to the forefront of Asia-Pacific countries, such as infectious diseases, environmental degradation and transnational crimes of human trafficking and drug

\footnotetext{
${ }^{8}$ Kenneth Waltz even goes so far to argue that interdependence reduces systemic stability by increasing the opportunities for conflict because states in an anarchic, self-help system "worry about securing that which they depend on." Waltz, Theory of International Politics, p. 106; also see Waltz, "The Myth of Interdependence," in (Kindleberger 1970, p. 205).

9 Scholars predicted a multipolar strategic quadrangle of the US, China, Japan, and Russia in the postCold War Asia-Pacific region. see, for example, (Solomon 1995, pp. 1996-208).
} 
trafficking. Unlike traditional security issues that could be handled bilaterally, combating these non-traditional security threats required multilateral cooperation and regional institutions (Kurlantzick 2007, pp. 68-69). It was after the end of the Cold War that the APEC forum institutionalized its summit system in 1993, ASEAN Regional Forum (ARF) was created in 1994 to connect Northeast and Southeast Asia together in a regional institutional framework, and the Shanghai Cooperation Organization (SCO) was launched to combat cross border crimes, particularly three forces (terrorism, fundamentalism, and extremism) in 1996.

The Asian financial Crisis of 1997 was another major event that changed political calculation in the Asia-Pacific because the crisis provided an opportunity for China to not only become a leading player but also integrate into the region. In the wake of the crisis, many Asian countries looked for the assistance and leadership of the US and Japan to bail them out of the crisis. Nevertheless, both the US and Japan responded slowly. In contrast, China made a highly symbolic move to announce its "stand-by-Asia" policy by firmly refusing devaluation of its currency. A Chinese devaluation would have set off competitive devaluation across the region. This "beggar thy neighbor" competition would have had devastating economic and political consequences for the whole region. Just a few years before, China's rapid rise was viewed with trepidation in many Southeast Asian capitals. China's positive response to the crisis in comparison to Japan's paralysis changed the "China threat" perception of many Asian countries. After the Asian financial crisis, China began to engage East Asian states by moving beyond traditional bilateralism with a more welcoming attitude toward multilateral regional institutions. Taking advantage of its rising power status, China became an enthusiastic proponent of regional cooperation in the Asia-Pacific (Zhao 2011, p. 58). In November 1997, an annual ASEANChina summit was launched. This was a prelude to the first summit of 10 ASEAN nations and China, Japan and Korea, known as ASEAN+3 Summit, in December 1997. At the summit, China announced a good-neighboring and mutual-trust partnership with ASEAN oriented towards the 21st century (Wang 1997, p. 1). ASEAN, thus, changed from being an anti-China club to China's strategic partner. The ASEAN+3 has become an important East Asian regional mechanism "to balance regional groups elsewhere in Europe and North America." It owed its roots to the idea of a "caucus without Caucasians," originally proposed by Malaysian Prime Minister Mahathir Mohamad in the early 1990s (Burton et al. 2005). One well-known achievement of ASEAN+3 mechanisms is the Chiang Mai Initiative (CMI) created in 2000 as a network of currency swap arrangements to provide short-term liquidity for countries facing financial pressures. It was from this perspective that one Korean scholar indicated that "the financial crisis was a turning point in the history of regional cooperation in East Asia" (Chung 2005, p. 35).

The September 11 terrorist attacks also accelerated institutionalized regionalism in the Asia-Pacific. Engaging in the global war on terrorism, the US diverted its attention away from the challenges of China's rise and looked to cooperate with China in dealing with regional security concerns. As a result, the framework of the six-party talks was created to end the North Korean nuclear crisis. Because of its success, some regional leaders have proposed to transform the framework into an institutionalized Northeast Asian Security organization. Another political 
development after the September 11 was the intensified rivalry between China and Japan for influence in the region after the relative decline of the US influence. This rivalry served as a catalyst for the proliferation of FTA agreements in the AsiaPacific. After Japan concluded its first FTA with Singapore in 2001, China announced a framework agreement for a FTA with ASEAN in 2002. In response, Japan began to negotiate its own FTA with ASEAN in the same year. Alarmed by Sino-Japanese competition, the South Korean government jumped ahead of Japan and signed an FTA with ASEAN in 2006. As a result of the competition between China and Japan, the ASEAN+3 frameworks have become the center of regional integration and "ASEAN is increasingly becoming a coherent, collective negotiating body in its relations" with China, Japan and South Korea (Aggarwal and Koo 2006 , p. 39). In commemoration of its 40th anniversary in 2007, ASEAN adopted a formal Charter, thus conferring a legal personality upon this intergovernmental organization (Arnold 2007, p. 13).

Although the changing political landscape in the Asia-Pacific has facilitated the development of structured regionalism and has even begun to foster an Asia-Pacific identity and regional community, building regional institutions is still a complex process. As all political exercises of some scope, regional institutions were built by national leaders in changing international environments to maintain their national identities and pursue their national interests. The adoption of structured regionalism involves "a calculated, deliberate, and discretionary strategy on the part of political elites" (Smith 1993, p. 406). From interdependence and changing regional political environments to regional cooperation and institution-building, each step involves a political decision. As a result, the sheer size and diversity of the region remain important variables to shape the complex political bargaining process among national leaders of big powers and medium- and small-sized nations in their movement toward structured regionalism. In comparison with Europe, institutionbuilding of regional cooperation in the Asia Pacific has been unique, manifested in the so-called ASEAN Way and the APEC Way of institution-building.

\section{The ASEAN Way of Regional Cooperation}

The ASEAN Way was an informal approach toward regional cooperation, developed by one of the first regional organizations in East Asia, the Association of Southeast Asian Nations (ASEAN) that was formed by five South East Asian member states of Indonesia, Malaysia, the Philippines, Singapore, and Thailand in 1967. Brunei joined in 1984, Vietnam in 1995, Laos and Burma (Myanmar) in 1997, and Cambodia in 1999. ASEAN emphasizes self-constraints, diplomacy of accommodation, consultations, dialogue and consensus and explicitly resists building enforcement or punitive mechanisms to deal with contentious issues that could interfere in the internal affairs of member states. ASEAN learned these lessons from the failure of its predecessor, the Association of Southeast Asia (ASA) created by Malaysia (Malaya at the time), the Philippines, and Thailand in 1961. The ASA was short-lived partially due to its failure in the attempt to resolve the territorial dispute between Malaysia and the Philippines in 1962 when the newly formed Malaysian Federation was to include the North Borneo state of Sahah, which 
was claimed by the Philippines. ASEAN, therefore, has tried to avoid arbitrary involvement in regional conflicts and searched for a practical minimum solution that all parties can live with by relatively unstructured discussions, informality and discreetness, and pragmatism in building regional peace and stability. This approach is one way to avoid the sensitive issue of national sovereignty. East Asian countries have always been reluctant to sign any agreement that might legitimize foreign intervention on what they regard as their domestic affairs. For example, sensitivities about national sovereignty were clearly an issue as the member states negotiated the U.S.-ASEAN Joint Declaration for Cooperation to Combat International Terrorism. ASEAN members did not sign it until the agreement recognized "the principles of sovereign equality, territorial integrity and nonintervention in the domestic affairs of other states" as the guiding principles of ASEAN diplomacy (Glosserman 2002).

Although ASEAN has established a number of formal mechanisms, such as the framework of discussion and consultations among member states on matters of mutual interests and the legal instruments to prevent and manage disputes, "the preferred ASEAN way of managing disputes is clearly outside the parameters of formal structures and institutions of conflict resolution" (Caballero-Anthony 2005, p. 64). It was "a process of identity building which relies upon the conventional modern principles of inter-state relations as well as traditional and culture-specific modes of socialization and decision-making that is prevalent in Southeast Asia" (Acharya 2011, p. 28). Following the informal approach, ASEAN has consciously avoided moving in the direction of institutionalized conflict resolution. Although the limited level and nature of institutionalization "led to some dissatisfaction with the pace of functional cooperation in the region and mounting criticisms from within non-bureaucratic but still elite ASEAN circles of the inadequacy of the structures created for foster cooperation" (Weatherbee 1993, p. 31), there is still not an ASEAN equivalent of Brussels as ASEAN has not attempted to establish a supernational structure to which national decision-making authority was even partially transferred.

From the ASEAN Way to APEC Way: Voluntarism and Open Regionalism

APEC, as the largest organization for economic cooperation in the region, has also struggled hard to take a soft approach and remain a loose regional forum to accommodate its extremely diversified membership. Before APEC, there was a nongovernmental effort to formulate a region-wide Pacific Economic Cooperation Council (PECC) in 1980. PECC's membership was tripartite in nature, including government officials, businessmen and scholars. It organized a number of working groups on issues such as fisheries and the environment, and held an annual Economic Outlook Conference plus workshops (Woods 1993, p. 89). In the wake of the end of the Cold War in the late 1980s, Asian-Pacific government leaders came to face a new world reality that the global economic system might move toward regional blocs. The renewed European integration of the EU would encompass all of Europe, and the Western Hemisphere scheme would encompass both American continents. 
The development that could be most threatening to the Asian-Pacific economies was the emergence of a North American economic regionalism via the formation of the NAFTA. Several East Asian nations planned to be annexed into NAFTA as associate members if they were invited. But the invitation never arrived. ${ }^{10}$ The NAFTA agreement itself may not necessarily threaten Asian countries, as Canada and Mexico already traded extensively with the US, but a further enlargement of the agreement on a solely geographic basis could have serious implications. Thus, American assurance that NAFTA would not discriminate against the Asian-Pacific countries were "viewed with some skepticism" (Soesasto 1993, p. 377). As an observer put it, "Are regional free trade agreements 'building blocs' toward global free trade, or are they strategic economic groupings designed to become more competitive vis-a-vis other blocs? If the latter... how should East Asian countries and others not part of a major bloc respond" (Preeg 1992, p. 88)? In frustration, both large and small countries in the Asia-Pacific saw their interests lying in the formation of a regional inter-governmental organization (Whalley 1993, pp. 96-97).

APEC was officially launched in 1989 with initial members from 12 nations: Australia, Brunei, Canada, Indonesia, Japan, South Korea, Malaysia, New Zealand, the Philippines, Singapore, Thailand, and the USA. In November 1991, APEC admitted China, Hong Kong, and Taiwan. In November 1993, Mexico and Papua New Guinea joined APEC, and Chile was admitted in 1994, bringing members to 18. APEC thus becomes an organization across the Pacific that involved all major powers in the Asia-Pacific as well as the America-Pacific. Russia, Vietnam, and Peru became official members in 1998 after being observers during a transition period. The APEC chair rotates annually among members and is responsible for hosting an annual ministerial meeting. Foreign and economic ministers of the member states first met in Canberra, Australia, in November 1989. Since then, annual ministerial meetings have being held. A annual summit started in 1993 and heads of APEC member states have met regularly since then.

APEC members include great powers of the United States, China and Japan as well as underdeveloped small economies such as Vietnam and Papua New Guinea. In terms of population, China has more than 1.3 billion people while Brunei has only about 320,000. Among the APEC members, there are democratic, authoritarian, and Leninist regimes; communist, socialist, and market economies, and historic and contemporary enemies. APEC members are referred as economies rather than states because two of them (Taiwan and Hong Kong) are not recognized by other members as sovereign states. It was striking that APEC was the only regional organization that included members who did not recognize each others' right to exist. This was most evident in the case of mainland China and Taiwan. They did not recognize each other's legitimacy. Therefore, special arrangements were made to include those two important economies in APECs operation. Following the Seattle model, Taiwan's president was not able to attend the summit meetings

\footnotetext{
${ }^{10}$ For example, the Prime Minister of Singapore, Goh Chok Tong, said at the Seattle Summit that "Singapore would accept readily an offer to join NAFTA to ensure that it could continue selling to the US market".
} 
because the PRC found his presence unacceptable, so Taiwan's senior economic and financial officials were sent in their places.

A multi-dimensional undertaking with an extremely diversified membership, APEC has struggled to make decisions on two controversial issues ever since its creation: one is the choice between a loose regional forum and a formal regional institution; and the other is the choice between an inclusive open regionalism and an exclusive regional bloc. ${ }^{11}$

\section{A Loose Forum versus Formal Institution}

Although APEC was originally proposed not as an institutionalized organization but an inter-governmental forum for the discussion of economic cooperation in the region, three basic models competed to influence the APEC institution-building efforts within the strands of intellectual thinking in governments and academic community at the very outset. The first was a minimal model, drawn from the early history of ASEAN. It advocated APEC as a community-building process rather than as an organizational structure, seeing the APEC meetings as a means of member states getting to know each other better. The second was OECD model, which would provide a venue for identifying and discussing international economic issues but not be a rule-based institution. The third was trade agreement model to achieve trade liberalization through a formalized process similar to that in NAFTA and EU (Morrison 1998, pp. 7-8).

Many Asian members looked for the first or second model of a loose organization in which members encouraged one another to liberalize their trade and foreign investments without formal negotiations and commitment. They argue that the Asia-Pacific region did quite well without formal institutional arrangements. Western members, notably the US, Canada, and Australia, were in favor of the third model although would accept the second model to a certain extent. They advocated a "tougher and more formalistic regionalism" (Smith 1994) and would like to see APEC to evolve into an organization like EU or at least OECD that negotiates binding and enforceable international treaties and regulations. Singapore's Permanent Secretary of Foreign Ministry Kishore Mahbubani described this controversy, as a "tension between the institution-building impulses of the Anglo-Saxon participants and the consensus-building impulses of the Asian participants" (Mahbubani 1995, p. 110).

At the second ministerial meeting in Singapore in July 1990, the joint statement referred to APEC as a "non-formal forum for consultation." There were no binding agreements of any sort, no secretariat, and no plan for heads of state to get together. APEC was at most a culmination of an "Asian-Pacific Diplomacy," composed of governmental and non-governmental forces (Woods 1993), and provided a forum for discussion on a broad range of economic issues of importance to the region. Given those initial reservations, APEC has moved a very long distance, under the

\footnotetext{
11 In a somehow different fashion, Vinod K. Aggarwal finds four schools of thought with respect to international institution-building in Asia-Pacific: (1) pure GATTists; (2) the GATT-consistent school of open regionalism; (3) skeptics of open regionalism; and (4) advocates of an Asian bloc (Aggarwal 1993, pp. 1036-2038).
} 
pressure of Western members, from an informal dialogue group toward a more formalized institution in the 1990s. According to agreement reached at the APEC ministers' meeting in Seoul in November, 1991, a permanent secretariat was established in Singapore in September 1992 and ten APEC working groups were established to develop activities which would contribute to its overall goal of expanding economic cooperation among the member countries. An Eminent Persons Group (EPG) was commissioned by APEC in 1992 to provide a vision statement for the 1993 Seattle ministerial meeting. The EPG's statement purported to advance institution-building efforts following Clinton's proposal for a Summit meeting of APEC, in spite of several ASEAN states' "suspicions of some hidden American agenda" (Manning and Stern 1994, p. 84).

The establishment of APEC summit meeting system was a significant move toward structured regionalism. President Clinton's proposal for an APEC Summit drew US media comparisons to President Harry Truman's role in establishing postwar security and economic structures in Europe. One State Department participant in the Seattle summit was quoted as saying, "You have to think of this as a bit like being at a NATO meeting in 1950". A "vision statement" at the inaugural APEC summit meeting in Blake Island near Seattle on November 20, 1993, looked forward to "deepening our spirit of community" in spite of the reservation of some East Asian leaders over the term "community." The Seattle Summit decided to hold annual summits. Indonesia hosted the second APEC Summit on November 16, 1994, which led to the Bogor declaration of APEC leaders which set the goal of free and open trade and investment in the AsiaPacific by year 2020. ${ }^{12}$ Japan held the third Summit in Osaka in November 1995. Apparently, institutionalizing the summits increased APEC's momentum toward a more structured regionalism. In the words of C. Fred Bergsten, Chairman of APEC's Eminent Persons Group, "the leaders in Seattle began the process of converting APEC from a purely consultative body into a substantive international institution" (Bergsten 1994, p. 21).

Although non-Asian members, particularly the United States, successfully pushed toward an institutionalized regime in the struggle for the organizational shaping of APEC, supranational objectives and institutions were never easily accepted by Asian national leaders who tried very hard to find as a "noninstitutionalized cooperation regime" (Chiang 2000, p. 179) a cooperative structure that facilitates the general aims of regionalism while confirming the legitimate national self-interests of all sovereign states involved. With the decline of its power in relative terms, the US could urge its views on the nations of Asia-Pacific but had less assurance that those views would be accepted. As a matter of fact, each member-state came to the APEC meetings with a separate agenda beside regional issues. It was striking that many leaders came to the first APEC summit in Seattle for purposes totally irrelevant to regional cooperation. The major purpose of China's

\footnotetext{
12 After intensive negotiation, the Declaration stated that "the pace of implementation will take into account the differing levels of economic development among APEC economies, with the industrialized economies achieving the goal of free and open trade and investment no later than the year 2010 and the developing economies no later than the year 2020. For the text of "APEC Economic Leader's Declaration of Common Resolve, “.
} 
president Jiang Zemin was to meet US president Bill Clinton. This was the first summit meeting between China and the US after the Tiananmen Incident in 1989. Jiang tried to secure China's most-favored-nation (MFN) status from the US, which was linked with its dismal human rights record when Clinton came to office in 1992. Thailand's Prime Minister Chuan Leekpai came to Seattle looking for US maintenance of special tariff exemptions and to avoid the threat of US-imposed trade sanctions. South Korea's president, Kim Yong Sam, wanted to confer with the US, China, and Japan on the developing North Korean nuclear threat. Taiwan's representative, Vincent Siew, the Economic Minister, sought the opportunity to hobnob with the very leaders who did not recognize his government. US president Bill Clinton took the opportunity to present himself as an effective world leader to an increasingly skeptical domestic and international audience (Ching 1993, p. 48).

In this case, APEC's institutionalization caused some East Asian nations to worry about domination by larger partners if APEC became a negotiation rather than a consultation body. In protesting President Clinton's initiative, the Malaysian government went so far as to boycott the Seattle Summit in 1993. The invocation of "community" in the Seattle vision statement also inspired much pre-summit agonizing behind the scenes, which forced the APEC leaders to make it clear that they did not aim at European federalist structures. In its 1994 report, the EPG explicitly retreated from the "community" concept in favor of the Chinese formulation of APEC as a "big family" (Clarke 1995, p. 94). These members believed that in this big family, "there is no need to waste time on lengthy processes of drafting legalistic texts, making them formally binding by requiring the formal ratification of international treaties by legislatures of each participant and setting up enforcement mechanisms" (Drysdale and Elek 1996, p. 125).

As a result, voluntarism, namely, making concessions or commitments voluntarily, has become an important norm of APEC. This soft approach, a spillover from the ASEAN Way, has thereafter become known as the APEC Way, conforming politically, economically, and culturally to the diversity in the Asia-Pacific. The main characteristics of the APEC Way are "acknowledging diversity; emphasizing flexibility and gradualness; observing the principles of respect, equality and mutual benefit for each other; reaching unanimity through consultation; respecting rights of self-determination and autonomy" (Ying 2006, p. 34). The APEC way of institution-building was an outcome of political negotiations and conscious calculations of national interest among large as well as medium- and small-sized sovereign states. In this calculation, political considerations, i.e., sovereignty and security concerns, often outweigh economic interdependence.

Unlike EU and NAFTA, to negotiate binding treaties, APEC has remained as a voluntary economic forum. Decisions were not made through voting mechanism but consensus building across the highly diverse membership. This consensus was not necessarily a unanimous consensus but what was called "flexible consensus" by Indonesian President Suharto in the 1994 Bogor Declaration, in which disagreements or objections were allowed to be expressed in a final consensus. Based on voluntarism and flexible consensus, APEC has never produced any binding treaties but only joint statements, declarations and action plans and agendas. They are not compulsory but guidelines for cooperation among member economies. This 
voluntary and flexible approach toward structured regionalism has aimed at preventing hegemonic dominance by taking into consideration of diversity of the member economies. As a result, this approach of stressing voluntarism over compulsion "attracts a variety of economies to the forum" (Chiang 2000, p. 190).

\section{Closed versus Open Regionalism}

Another controversial issue that APEC confronted was a global versus regional dilemma. The March toward a single market in Europe and the free-trade agreement in North America gave impetus to a search for Asian alternatives. In the first phase of the APEC proposal, both Japan and some ASEAN countries were eager to create an exclusive East Asian bloc as a counterweight to Europe and North America, although some ASEAN members were equally concerned about Japanese or Chinese dominance in the region. This membership proposal was co-opted by US Secretary of State James Baker's mid-year tour to Asia, which cast the US as a catalyst for cooperation. The US is not an Asian country but has crucial economic and security interests in the region. The sheer volume of Asia-Pacific commerce gave rise to a US idea of the Pacific community which encouraged like-minded, liberally oriented states to form a "building block" of world-wide trade liberalization on a nondiscriminatory basis rather than a stumbling trade block.

This position was expressed by the US government as "a vision of open regionalism." 13 This vision came with two organizational aspects. One was a commitment of APEC to accept Asian-Pacific as well as American-Pacific members. A report of Washington-based Carnegie Endowment for International Peace claimed that the decision to include the US and Canada ensured "APEC would not become a Fortress Asia, but a potentially important regional anchor for the global trading system" (The Carnegie Endowment Study Group 1994, p. 27). The second aspect of open regionalism was to reassure the commitment of APEC not to be an exclusive economic bloc and not to follow protectionist policies that by definition discriminated against non-members. In other words, open regionalism would prevent discrimination by ensuring that agreements at the regional level are extended to any country willing to reciprocate the terms of the agreement.

It is interesting that although APEC came amid rising threats of protectionism and emerging economic blocs in the world, APEC was created according to the principle of "open regionalism" as distinct from the closed regionalism being pursued in Europe and North America. Following the principle of open regionalism, within the first two years of its creation, APEC expanded to accept members not only from the Asia-Pacific but also from North and South America. Its expansion went quickly beyond its original core of East Asia and Western Pacific developed and emerging economies. Concerns arose that "further expansion would result in APEC's loss of focus and cohesiveness" (Morrison 1998, p. 9). As a result, a 3 year moratorium on new members was declared in 1994.

\footnotetext{
13 For one official expression of US position, see Secretary Warren Christopher's speech at the APEC Ministerial meeting in Jakarta, Indonesia on November 11, 1994, "Transforming the APEC Vision into Reality,".
} 
As a matter of fact, some East Asian leaders were reluctant to accept the idea of open regionalism from the very beginning because of at least the following three concerns. The first was a set of questions about how it would work. What advantages would there be in APEC membership if one could enjoy the benefits separately? Would potential APEC regulations regarding internal economic practices such as government procurement and competition policy apply to nonAPEC countries seeking agreement? The second concern was over a two-faced approach as the US claimed to be an Asia-Pacific nation yet formed its own exclusive trading group in the form of NAFTA. ${ }^{14}$ In a 1991 speech to the UN, Mahathir said: "In East Asia we are told we may not call ourselves East Asians as Europeans call themselves Europeans and Americans call themselves Americans. We are told that we must call ourselves Pacific people and align ourselves with people who are only partly Pacific, but more American, Atlantic, and European" (Awanohara 1991, p. 13). The third was "the fear that APEC could become a field for power projection by the United States" (Emmerson 1994, p. 438). Kiyoaki Kiteuchi, senior advisor to Matsushita Electric and Japan's former Vice-Foreign Minister for Economic Affairs in the early 1980s, saw APEC as "a second Open Door policy recalling the US attempt to open China to Western trade and investment in the 1890s" (Smith 1994, p. 50).

These concerns led Malaysian prime minister, Datuk Seri Mahathir Mohamad, to announce in December 1990 the idea of forming a bloc where only bona fide Asian nations were included and the US and even Australia were excluded. Mahathir named it East Asia Economic Grouping (EAEG), and argued that EAEG, including ASEAN members, Hong Kong, Taiwan, Japan, South Korea, and China, would give greater bargaining power to East Asian countries in negotiations with the US and Western Europe, which he felt were the moving precipitously toward exclusive trading blocs. Prime Minister Mahathir was known as the originator of Malaysia's "Look East" policy, which urged Malaysians to emulate the discipline of the Japanese (Bresnan 1994, p. 46). Tempted by the opportunity to establish an advantaged position in East Asia's dynamic markets, Japanese leaders, in private, expressed interest for Mahathir's idea, while, in public, made statements wary of the proposal. Former Japanese foreign minister, Saburo Okita who planned the postwar renaissance of the Japanese economy, wrote approvingly of the idea: "The EAEG was clearly formulated within a context of concern that Asia would be the loser as Europe and North America rushed to establish their own economic blocs" (Awanohara 1991, p. 27).

Nevertheless, Mahathir's proposal was sharply criticized by the United States. Washington opposed the proposal with unusual vigor. James Baker, Secretary of State in the Bush Administration, wrote to Japanese Foreign Minister Michio Watanable and said that the EAEG would "divide the Pacific region in half" and asked Japan not to participate. He also put strong pressure on the government of South Korea to oppose EAEG (Awanohara 1991, p. 26). Under these circumstances, most East Asian governments became noncommittal because they felt they could

\footnotetext{
14 It is argued that the NAFTA concept has encouraged the creation of a narrow, geographically or racially defined Asian regionalism. (Soesasto 1993, p. 377).
} 
not risk alienating the US (Petri 1994, p. 410). Even some of Malaysia's ASEAN partners were troubled by Malaysia's confrontational leadership and preferred the large framework of APEC where they could benefit from American trade and investment while playing the US off against Japan and perhaps China. ASEAN economic ministers met in Kuala Lumpur in October 1991 and agreed to a watereddown version of the Mahathir proposal as the East Asian Economic Caucus (EAEC) that could operate inside APEC. Membership met on an ad hoc basis, as need arose (Bresnan 1994, p. 47). In return, to mollify ASEAN's fears of domination by the US, Japan, or China, APEC agreed to hold alternative annual meetings in a Southeast Asian country (Emmerson 1994, p. 438).

Although the EAEG proposal was essentially aborted after re-cast as the East Asian Economic Caucus (EAEC), the idea remained alive in nongovernmental circles, and there appeared to be a growing number of proponents. An exclusive Asia-Pacific regional organization was seen as the most important insurance against the perceived trend toward regional blocs in Europe and North America, exactly in the way Mahathir proposed it initially. Some believe that the coming of the AsiaPacific century led to the emergence of an East Asian community characterized by a high degree of regional integration. This belief led to the creation of East Asian Summit (EAS) in 2005 and the US was not invited in the three EASs that have convened. EASs "could become the critical Asian Institution," (Kurlantzick 2007, p. 73) although they haven't yielded much because the rival of China and Japan over historical, political, and economic issues, including the sovereignty disputes over controversial territories in East China Sea (Twining 2007).

The dispute regarding APEC's institution-building reflects a careful calculation of Asian Pacific countries in choosing structured regionalism. Although the sheer size and diversity of nations in the region failed to prevent structured regionalism from emerging, it made institution-building a very complicated task. Asia-Pacific leaders accepted the APEC idea due to their fear that their countries would be left outside emerging trade blocs in the world. However, unlike the European and North American regionalism that came into being at "big bang" institutions, structured regionalism in the Asia-Pacific has proceeded by a much more incremental process in which many controversies had to be settled before institutions could be built.

\section{Conclusion}

The development of Asia-Pacific regionalism shows an evolutionary and multifaceted approach toward organization choice and institution-building. While soft regionalism is still an important form of cooperation in the region, the post-Cold War political changes have brought the strong interest in an institutional approach toward handling regional economic and security issues. The emergence of structured regionalism constitutes a significant structural change that may eventually lead to a substantial reorganization of the Asia-Pacific. Nation-states are still the principal actors in the region and behave on the basis of their perceptions of selfinterest. Relative capabilities and distribution of power remain important, and states must rely on their economic and political capacities to assure themselves gains from 
cooperation. Nevertheless, regionalism plays an important role in changing conceptions of national interests. Each state has to find its proper place in a cooperative relationship, structured or soft, with its neighboring states and regional powers.

Economic interdependence is an important variable that broke down Asian parochialism and encouraged Asians to rethink their relationships in the terms of soft or structured regionalism. Nevertheless, structured regionalism has developed under a changing political environment, and organizational choice for regional cooperation is a political decision made by sovereign states based upon a conscious calculation of economic as well as political interests. Seeking to preserve their sovereignty and freedom of action, Asia-Pacific nations have showed caution and flexibility in developing regional institutions. On the one hand, the movement to institutionalize Asian-Pacific regional cooperation in the form of APEC marked the most important progress toward a structural regionalism. On the other hand, regional diversity is still the fundamental background conditions of the movement to institutionalize regional cooperation in the Asia-Pacific and has given rise to the APEC Way of institution-building.

\section{References}

Acharya A (2011) Constructing a security community in Southeast Asia: ASEAN and the problem of regional order. Routledge, London

Aggarwal VK (1993) Building International Institutions in Asia-Pacific. Asian Surv 33:11

Aggarwal V, Koo MG (2006) Economic and security regionalism shifting ground: Is it finally time? Glob Asia $1: 1$

Akamatsu K (1962) A historical pattern of economic growth in developing countries. Dev Econ (1)

Arnold W (2007) Asean leaders sign historic charter. International Herald \& Tribune, London

Awanohara S (1991) Rich man, poor man. Far Eastern Economic Review, vol 154, no 40, October 3

Axelrod R (1967) Conflict of interest: an axiomatic approach. J Confl Resolut 11:1

Axelrod R, Keohane R (1993) Achieving Cooperation under Anarchy: strategies and Institutions. In: David AB (ed) Neorealism and neoliberalism: the contemporary debate. Columbia University Press, New York

Baldwin DA (1980) Interdependence and power: a conceptual analysis quick view. Int Organ :34(4): 471-506 (Autumn)

Barkin JS, Cronin B (1994) The State and the Nation: changing norms and the rules of sovereignty in international relations. Int Organ 48:1 (winter)

Bergsten F (1988) America in the World economy: a strategy for the 1990s. Institute for International Economics, Washington, DC

Bergsten CF (1994) APEC and World trade: a force for Worldwide liberalization. Foreign Affairs 73:3

Bradford C Jr (1987) Trade and structural change: NICs and next tier of NICs as transitional economies. World Dev 15:3

Bresnan J (1994) From Dominoes to Dynamos: the transformation of Southeast Asia. Council on Foreign Relations Press, Washington, DC

Burton J, Mallet V, McGregor R (2005) A new sphere of influence: how trade clout is winning China allies yet stoking distrust. The Financial Times, London 9

Caballero-Anthony M (2005) Regional security in Southeast Asia: beyond the ASEAN way. Institute of Southeast Asian Studies, Singapore

Chiang JCC (2000) Conceptualizing the APEC way: International Cooperation in a non-institutionalized regime. Issues Stud 36:6

Ching F (1993) At APEC summit, everyone won. Far East Econ Rev 156:42 
Chow PCY (1993) Asia Pacific economic integration in global perspective. In: James CH (ed) Asia Pacific in the new World politics. Boulder, Lynne Rienner

Chung JY (2005) East Asian regionalism: moving forward, South Korea and East Asian regionalism: which path ahead? Challenges Posted by the DPRK for the alliance and the region. Korea Economic Institute, Washington, DC

Clarke J (1995) APEC as a semi-solution. Orbis 38:1

Cooper RN (1968) The economics of interdependence: economic policy in the Atlantic community. McGraw-Hill, New York

Cooper RN (1972) Economic interdependence and foreign policy in the seventies. World Politics 24:2

Crone D (1993) Does hegemony matter? The reorganization of the Pacific political economy. World Politics 45:4

Cui S (2013) Beyond history: non-traditional security cooperation and the construction of Northeast Asian International Society. J Contemp China 22:83

Dent CM (1999) The European Union and East Asia: an economic relationship. Routledge, London

Drysdale PD, Elek A (1996) Towards APEC's liberalization goals of 2010 and 2020. In: Ippei Y, Akira H (eds) APEC: cooperation from diversity. Institute of Developing Economic, Tokyo

Emmerson DK (1994) Organizing the Rim: Asia Pacific regionalism. Curr Hist 93:587

Falk R (1975) A study of future Worlds. The Free Press, New York

Fields KJ (1992) Circling the wagons: the trend toward economic regionalism and its consequences for Asia. Issues Stud 28:12

Gaddies JL (1989) The Post-War International system: elements of stability and instability. In: Bruce R, Harvey S, Richard JS (eds) Choices in World politics: sovereignty and interdependence. W H Freeman and Company, New York

Ganesan N (1993) Conceptualizing regional economic cooperation: perspectives from political science. In: Toh MH, Linda L (eds) Regional cooperation and growth triangles in ASEAN. Times Academic Press, Singapore

Gilpin R (1993) The debate about the new World economic order. In: Danny U, Paul B (eds) Japan's emerging global role. Lynn Rienner Publishers, Boulder

Glaster CL (1994/95) Realists as optimists: cooperation as self-help. Int Secur Winter 19:3

Glosserman B (2002) ARF is now a big dog barking. Global beat syndicate. http://www.bu.edu/ globalbeat/syndicate/glosserman082602.html. Accessed 26 Aug 2002

Gordon BK (1993) Japan: searching once again. In: James CH (ed) Asia Pacific in the new World politics. Lynne Rienner, Boulder

Herz J (1968) The territorial state revisited: reflections on the future of the Nation-State. Polity, vol 1, no 1 , pp 11-34

Hidetaka Y (2006) Business interests and regionalism in East Asia. RCAPS News1 5:5

Hirono R (1988) Future prospects for economic cooperation in Asia and the Pacific region. In: Robert AS, Masataka K (eds) Peace, politics and economics in Asia: the challenge to cooperate. PergamonBrassey's International Defense Publishers, Washington, DC

Inoguchi T (1994) The coming Pacific century. Curr Hist 93:579

Keohane RA (1984) After hegemony: cooperation and discord in the World political economy. Princeton University Press, Princeton

Kim S (1991) Mainland China and a new World order. Issues Stud 27:11

Kindleberger CP (1970) The International Corporation. The MIT Press, Cambridge

Kindleberger C (1975) The World in depression, 1929-1939. University of California Press, Berkeley

Krasner S (1976) State power and the structure of international trade. World Politics 28:3

Kurlantzick J (2007) Pax Asia-Pacifica? East Asian integration and its implications for the United States. The Washington Quarterly, vol 30, no 3, pp 66-77

Lu Z (1993) Northeast Asian Economic Cooperation in the Post-Cold War Era. Institute on Global Conflict and Cooperation Policy Paper, \#6, University of California, San Diego

Mahbubani K (1995) The Pacific war. Foreign Affairs 74(1):100-111

Manning RA, Stern P (1994) The Myth of the Pacific community. Foreign Affairs 37:6

Marton A, McGee T, Paterson DG (1995) Northeast Asian economic cooperation and the Trumen River area development project. Pacific Affairs 68:1

McCord W (1993) The Dawn of the Pacific century, implications of the three Worlds of development. Transaction Publishers, New Brunswick

Milner H (1993) The assumption of anarchy in international relations theory: a critique. In: David AB (ed) Neorealism and neoliberalism: the contemporary debate. Columbia University Press, New York 
Mitrany D (1975) The functional theory of politics. St. Martin's, London

Moore GJ (2013) Constructing cooperation in northeast Asia: historical northeast Asian Dyadic cultures and the potential for greater regional cooperation. J Contemp China 22:83

Morrison CE (1998) APEC: The evolution of an Institution. In: Vinod KA, Charles EM (eds) Asia-Pacific crossroads: regime creation and the future of APEC. St. Martin's Press, New York

Nye JS (1977) Power and Interdependence: World politics in transition. Little Brown, Boston

Petri PA (1994) Trading with Dynamos: East Asian interdependence and American interests. Curr Hist 93:587

Preeg EH (1992) The US leadership role in the world trade: past, present, and future. Wash Quart 15:2

Rosecrance R (1986) The rise of the trading State. Basic Books, New York

Rosenau J (1968) National Interest. International encyclopedia of the social sciences, vol. 11. Macmillan, New York

Scalapino RA (1987) Major power relations in Northeast Asia. University Press of America, Lanham

Schelling TC (1960) The strategy of conflict. Harvard University Press, Cambridge

Seymour JD (1994) Human rights in Chinese foreign relations. In: Samuel SK (ed) China and the World. Westview Press, Boulder

Smith P (1993) The politics of integration, guidelines for policy. In: Smith C (ed) The challenge of integration: Europe and the Americas. Transaction Publishers, New Brunswick

Smith C (1994) The politics of economics. Far Eastern Economic Review, vol 157, no 23, June 9, p 48

Soesasto H (1993) Implications of the Post-Cold War politico-security environment for the Pacific economy. In: Fred Bergsten C, Marcus N (eds) Pacific Dynamism and the International economic system. Institute for International Economics, Washington, DC

Solomon RH (1995) Who will shape the emerging structure of East Asia? In: Mandelbaum Michael (ed) The strategic quadrangle: Russia, China, Japan and the United States in East Asia. Council on Foreign Relations Press, New York

The Carnegie Endowment Study Group (1994) Defining a Pacific community. Carnegie Endowment for International Peace, Washington, DC

Twining D (2007) The new Asian order's challenge to China. The Financial Times, September 25

Waltz K (1979) Theory of international politics, reading. Addison-Wesley Pub. Co, Mass

Wang Y (1997) China, ASEAN stress peace: summit agrees on approach. China Daily, December 17, p 3

Weatherbee D (1993) ASEAN and evolving patterns of regionalism in Southeast Asia. Asian J Political Sci $1: 1$

Whalley J (1993) The Uruguay round and the GATT: whither the global system. In: Fred Bergsten C, Marus N (eds) Pacific Dynamism and the International economic system. Institute for International Economics, Washington, DC

Woods LT (1993) Asia-Pacific diplomacy, non-governmental organizations and international relations. UBC Press, Vancouver

Ying M (2006) Searching for a peace community: regional cooperation in Northeast Asia. J East Asian Affairs 20:1 (spring/summer 2006)

Yue CS, Yuan LT (1993) Subregional economic zones: a new motive force in Asia-Pacific development. In: Fred Bergsten C, Marus N (eds) Pacific dynamism and the international economic system. Institute for International Economics, Washington, DC

Zhao S (2011) China's approach toward regional cooperation: motivations and calculations. J Contemp China 20:68 